\title{
ANALISIS PERHITUNGAN CADANGAN KERUGIAN PENURUNAN NILAI PT. BANK BRI AGRONIAGA TBK CABANG PEKANBARU TAHUN 2016
}

\author{
Jeli Nata Liyas \\ Jurusan Manajemen Fakultas Ekonomi STIE RIAU \\ jaznatan@yahoo.co.id
}

\begin{abstract}
This study analyzes the calculation of fund formation Allowance for impairment losses according to banking rules and according to the tax rules. Allowance for impairment on an allowance is established when the carrying value after impairment are less than the carrying amount of the initial. Recognition of allowance for impairment in accordance with banking regulations by Indonesian Banking Accounting Guidelines, while according to the tax rules on the terms of Regulation of the Minister of Finance No.81/PMK.03/2009. Fiscal correction is used to adjust for differences in the recognition of allowance for impairment in accordance with banking rules and according to the rules of taxation. Analysis of the data used is quantitative descriptive analysis. The analysis showed that there was no difference according to the allowance for impairment recognition PT. Bank BRI Agroniaga, Tbk with banking rules. The same is shown in the application of fiscal correction to the allowance for impairment of PT. Bank BRI Agroniaga, Tbk accordance with the tax regulations. This means recognition of allowance for impairment of PT. Bank BRI Agroniaga, Tbk has appropriate banking regulation and taxation.
\end{abstract}

Keywords: Allowance for impairment losses, Banking Rules, Rules of Taxation, Fiscal Correction

\begin{abstract}
Abstrak
Penelitian ini menganalisis perhitungan pembentukan dana Cadangan Kerugian Penurunan Nilai menurut aturan perbankan dan menurut aturan pajak. CKPN merupakan penyisihan yang dibentuk apabila nilai tercatat kredit setelah penurunan nilai kurang dari nilai tercatat awal.Pengakuan CKPN menurut aturan perbankan berdasarkan Pedoman Akuntansi Perbankan Indonesia, sedangkan menurut aturan perpajakan berdasarkan Peraturan Menteri Keuangan No.81/PMK.03/2009.Koreksi fiskal digunakan untuk menyesuaikan perbedaan pengakuan CKPN menurut aturan perbankan dan menurut aturan perpajakan. Analisis data yang digunakan adalah analisis deskriptif kuantitatif. Hasil analisis menunjukkan bahwa tidak terdapat perbedaan pengakuan CKPN menurut PT. Bank BRI Agroniaga, Tbk dengan aturan perbankan. Hal yang sama juga ditunjukkan pada penerapan koreksi fiskal terhadap CKPN PT. Bank BRI Agroniaga, Tbk telah sesuai dengan aturan perpajakan. Hal ini berarti pengakuan CKPN PT. Bank BRI Agroniaga, Tbk telah sesuai aturan perbankan dan perpajakan.
\end{abstract}

Kata kunci: Cadangan Kerugian Penurunan Nilai (CKPN), Aturan Perbankan, Aturan Perpajakan, Koreksi Fiskal 


\section{PENDAHULUAN}

Perbankan merupakan salah satu sarana pembiayaan yang didukung oleh pemerintah untuk mendorong pertumbukan perekonomian Indonesia, adanya dukungan pemerintah akan pembangunan dari segala sektor terutama sektor ekonomi. Dukungan pemerintah tersebut salah satunya lebih bertumpu pada perkembangan UMKM di Indonesia yang di dukung dengan pembiayaan usahanya. Pemerintah tidak serta merta hanya sebagai pendukung tapi juga pengatur, salah satunya pengaturan penerimaa Negara dari sumber pajak.

Dimana Pajak memiliki peran penting untuk memenuhi kebutuhan anggaran penerimaan pemerintah. Pada masa Orde Baru pajak dititikberatkan sebagai sumber utama pendapatan negara Indonesia. Sistem pemungutan pajak yang berlaku di Indonesia saat ini adalah self assessment system. Dimana Wajib Pajak (WP) diwajibkan untuk menghitung jumlah pajaknya sendiri dan melaporkan pajaknya ke administrasi perpajakan. Sistem ini akan aktif diterapkan dalam suatu negara apabila kondisi kepatuhan sukarela (voluntary compliance) yang ada pada diri setiap masyarakat telah terbentuk (Damayanti, 2004). Self assessment systemtelah dianggap menjadi nilai dan norma di masyarakat taat pajak.

Teori Legitimasi menjelaskan suatu organisasi hanya bisa bertahan dimasyarakat apabila organisasi tersebut beroperasi sesuai dengan nilai dan norma yang beredar di masyarakat (Zaenuddin, 2007). Legitimasi adalah persepsi umum bahwa tindakan entitas yang diinginkan tepat dalam suatu sistem sosial yang dibangun dari norma, nilai, keyakinan dan definisi (Suchman, 1995). Dowling \& Pfeffer (1975) menyatakan bahwa legitimasi merupakan hal yang penting bagi entitas. Teori ini bergantung pada gagasan bahwa antara perusahaan dan masyarakat tempat perusahaan beroperasi terdapat kontrak sosisal (Patten, 1991). Dalam mengadopsi perspektif teori Legitimasi, perusahaan akan sukarela melaporkan kegiatan jika manajemen merasakan bahwa kegiatan tersebut diharapkan oleh masyarakat di mana ia beroperasi (Deegan., Rankin dan Voght, 2000; Cornier dan Gordon, 2001; Deegan, 2002)

Wijayanti (2006) mengatakan manajemen menghitung laba perusahaan untuk dua tujuan setiap tahunnya, yaitu tujuan pelaporan keuangan dan pelaporan pajak. James (2002) mengatakan tujuan dan persyaratan prinsip akuntansi keuangan dan pajak tidak selalu sama. Duhanxhiu dan Kapllani (2012) menjelaskan dalam penelitiannya, bahwa aturan akuntansi dan aturan pajak adalah dua konsep yang dikembangkan oleh otoritas yang berbeda dan digunakan untuk tujuan yang berbeda pula. Freedman (2004) menambahkan laporan keuangan komersial dan laporan keuangan pajak memiliki tujuan dan persyaratan berbeda. Standar akuntansi keuangan dan peraturan perpajakan sering memberikan aturan yang spesifik dan sering berbeda, mengenai bagaimana melaporkan pendapatan untuk tujuan komersial dan pajak, meskipun laporan pendapatan keduanya didasarkan pada transaksi dasar yang sama pada umumnya (Mills et al., 2002). Shaviro (2008) juga menjelaskan bahwa konsep akuntansi keuangan dan akuntansi pajak tidaklah identik dan memiliki tujuan yang berbeda dalam prakteknya. Menurut Green (1995) dalam penelitiannya menyatakan satu pandangan yang jelas dari Amerika Serikat menyatakan bahwa akuntansi keuangan dan akuntansi perpajakan tidak sama, konsep tersebut memiliki tujuan yang berbeda, 
tunduk pada aturan yang berbeda dan melayani tujuan yang berbeda.

Djamluddin dalam Purwanti, dkk (2017), hampir semua perhitungan laba akuntansi yang dihasilkan mengalami koreksi fiskal. Menurut Amelia, dkk (2017), koreksi fiskal dilakukan oleh WP dikarenakan terdapat perbedaan perhitungan, khususnya laba menurut akuntansi dengan laba menurut pajak. Koreksi fiskal tersebut dibagi dalam dua kelompok, yaitu koreksi positif dan koreksi negatif.

Perbedaan pengakuan dan pengukuran pendapatan atau biaya menurut akuntansi dan menurut pajak dapat dikelompokkan menjadi perbedaan tetap dan perbedaan waktu (Temporer). Pahala, dkk. (2012) beda tetap biasanya timbul karena peraturan pajak yang mengharuskan penghasilan telah dikenakan Pajak Penghasilan (PPh) Final, penghasilan yang bukan objek pajak dan biaya yang tidak berhubungan dengan kegiatan usaha dikeluarkan dari Penghasilan Kena Pajak (PKP). Beda waktu biasanya timbul karena adanya perbedaan alokasi waktu pengakuan pendapatan atau biaya menurut akuntansi dan pajak. Beda waktu yang dapat menambah jumlah pajak masa depan akan diakui sebagai utang pajak tangguhan, sebaliknya beda waktu yang mengurangi jumlah pajak di masa depan akan diakui sebagai asset pajak tangguhan (Phillips et al., 2003).

Perbedaan pengakuan pendapatan atau biaya menurut akutansi dan pajak sendiri dapat dilihat pada Cadangan Kerugian Penurunan Nilai (CKPN). CKPN merupakan penyisihan yang dibentuk apabila nilai tercatat kredit setelah penurunan nilai kurang dari nilai tercatat awal (PAPI, 2008). Cadangan Kerugian Penurunan Nilai (CKPN) adalah jumlah yang diturunkan dari nilai tercatat hingga menjadi sebesar nilai yang dapat diperoleh kembali dari aset (Febriati, 2011). CKPN merupakan dana cadangan khusus yang dibentuk pihak perbankan untuk menanggulangi risiko kredit yang tidak dapat ditagih kembali. Pembentukan dana CKPN berdasarkan dari penilaian kredit yang dilakukan pihak perbankan.

Penilaian kredit adalah proses menetapkan ukuran kuantitatif tunggal atau skor untuk peminjam potensial melalui perkiraan kinerja kredit peminjam di masa depan (Feldman, 1997).Pedoman pengakuan dan pengukuran CKPN yang digunakan pihak perbankan adalah Pedoman Akuntansi Perbankan Indonesia (PAPI) 2008 yang mana telah mengacu pada PSAK 55 revisi 2016. Pedoman pengakuan dan pengukuran CKPN menurut perpajakan diatur dalam Peraturan Menteri Keuangan Nomor 81/PMK.03/2009. Hasil dari beberapa penelitian sebelumnya menunjukkan adanya perbedaan antara pengakuan pendapatan dan biaya menurut akuntansi dengan pajak.HasilpenelitianLumbatoruan (2002),menyimpulkan bahwa ada perbedaan antara laba kena pajak kedua laporan keuangan setiap tahunnya. Penelitian yang dilakukan oleh Natalia dan Syafitri (2017), menunjukkan bahwa terdapat perbedaan jumlah laba CV Tamba dalam laporan keuangan komersial dengan laporan keuangan fiskal. Hal tersebut juga didukung oleh Sari dan Lidyah (2017) dan Lawrensius, dkk.(2017), yang juga menyatakan bahwa adanya perbedaan antara laba akuntansi dengan laba untuk tujuan pajak.Hasil penelitian Dita dan Khariani (2017) menyimpulkan bahwa pelaksanaan pajak yang dilakukan oleh PT. Citra Karya Sejati belum maksimal dalam mengoreksi laporan keuangan komersial yang dimiliki berdasarkan peraturan perpajakan.

Salah satu bank yang membentuk dana 
CKPN adalah PT. Bank BRI Agroniaga, Tbk. Dimana merupakan bank swasta mandiri yang berdiri semenjak 27 September 1989. PT. Bank BRI Agroniaga, Tbk merupakan salah satu bank swasta terbaik di Indonesia yang mampu bersaing dengan bank-bank besar umum lainnya dan terlebih lagi sudah di akuisisinya PT. Bank BRI Agroniaga, Tbk sejak tahun 2016 yang sebelumnya bernama PT. Bank Agroniaga, Tbk. Bank BRI Agroniaga, merupakan bank memiliki fokus kepada pembiayaan terhadap pertanian. Hal ini terbukti dengan kurun waktu 5 tahun ini dan telah meraih banyak penghargaan, termasuk salah satunya The Best Bank in Financial Aspect pada tahun 2015 sebagai peringkat ketiga (Bank BRI Agroniaga, 2016).

Berdasarkan uraian latar belakang di atas, rumusan masalah dalam penelitiannya adalah apakah perhitungan CKPN PT. Bank BRI Agroniaga, Tbk tahun 2016 telah sesuai dengan aturan perbankan dan perpajakan?

\section{METODE PENELITIAN}

Penelitian ini mengambil lokasi di Kantor PT. Bank BRI Agroniaga, Tbk Cabang Pekanbaru. Perusahaan ini berlokasi di Jalan Sudirman No.231 Pekanbaru. Berdasarkan sumbernya, data yang digunakan dalam penelitian ini adalah informasi mengenai gambaran PT. Bank BRI Agroniaga, Tbk, laporan keuangan tahunan, data kelompok kredit dan nilai agunan dari masing-masing kredit serta kolektibilitas kredit PT. Bank BRI Agroniaga, Tbk tahun 2016.

\section{Teknik Pengumpulan Data}

1) Observasi lapangan

Observasi lapangan dilakukan untuk mendapatkan data dari perusahaan melalui wawancara dengan pejabat perusahaan yang berwewenang. Dalam penelitian ini, peneliti melakukan pengamatan terhadap laporan keuangan PT. Bank BRI Agroniaga, Tbk.

2) Dokumentasi

Menurut Arikunto (2006:158) dokumentasi adalah mencari dan mengumpulkan data mengenai hal-hal yang berupa catatan, transkip, buku, surat kabar, majalah, notulen, raport, agenda dan sebagainya. Dalam penelitian ini metode dokumentasi dilakukan mengumpulkan berkas-berkas data kelompok kredit dan nilai agunan dari masing-masing kredit serta kolektibilitas kredit PT. Bank BRI Agroniaga, Tbk tahun 2016.

\section{Teknik Analisis Data}

Analisis data yang digunakan dalam penelitiian ini adalah analisis deskriptif kuantitatif, dimana teknik-teknik yang dilakukan adalah mengumpulkan data perusahaan yang berkaitan dengan permasalahan melalui observasi langsung dan wawancara dengan pejabat terkait serta dokumentasi data, melakukan pemeriksaan terhadap laporan keuangan yang dilakukan oleh pihak bank, menganalisis perbandingan perhitungan cadangan kerugian penurunan nilai PT. Bank BRI Agroniaga, Tbk Cabang Pekanbaru menurut aturan perbankan dengan peraturan perpajakan.

\section{HASIL DAN PEMBAHASAN}

Total kredit yang diberikan dan cadangan kerugian penurunan nilai PT. Bank BRI Agroniaga, Tbk hingga akhir 2015 dan 2016 dijelaskan pada tabel 1 dan 2 berikut. 
Tabel 1.

Kredit yang Diberikan PT. Bank BRI Agroniaga, TBK hingga Akhir Tahun 2015 dan 2016

\begin{tabular}{l|lr|lr}
\hline \multicolumn{1}{c|}{ Keterangan } & \multicolumn{2}{c|}{ 31 Desember 2016 } & \multicolumn{2}{c}{ 31 Desember 2015 } \\
\hline Lancar & Rp. & 304.984 .497 .880 & Rp. 307.304 .912 .182 \\
Dalam Perhatian Khusus & Rp. & 8.786 .988 .139 & Rp. & 6.544 .174 .350 \\
$\quad$ Kurang Lancar & Rp. & 12.663 .985 & Rp. & 105.677 .176 \\
$\quad$ Diragukan & Rp. & 492.073 .261 & Rp. & 107.854 .871 \\
Macet & Rp. & 14.514 .214 .585 & Rp. & 19.634 .404 .763 \\
Jumlah & Rp. 328.790.439.886 & Rp. 333.697.025.357 \\
Cadangan Kerugian Penurunan Nilai & Rp. $(13.766 .883 .068)$ & Rp. $(14.204 .503 .871)$ \\
Total & Rp. 315.023.556.798 & Rp. 319.492.512.486 \\
\hline
\end{tabular}

Sumber: Data diolah, 2017

Dari tabel 1 di atas, total kredit hingga akhir 2016, menurun sebesar $1.01 \%$ dibandingkan dengan total kredit akhir tahun 2015. Total kelompok kredit lancar, kurang lancar dan macet pada akhir tahun
2016 mengalami penurunan dari akhir tahun 2015, sedangkan untuk total kelompok kredit dalam perhatian khusus, kurang lancar dan diragukan pada tahun 2016 mengalami peningkatan dari tahun 2015.

Tabel 2.

\section{Cadangan Kerugian Penurunan Nilai PT. Bank BRI Agroniaga, Tbk hingga Akhir Tahun 2016 dan 2015}

\begin{tabular}{l|l|l}
\hline \multicolumn{1}{c|}{ Keterangan } & \multicolumn{1}{|c}{ 31 Desember 2016 } & \multicolumn{1}{|c}{ 31 Desember 2015 } \\
\hline Saldo awal tahun & Rp.(15.337.030.338) & Rp.( 14.703.646.843) \\
Cadangan yang dibentuk Penghapusan & Rp.(11.392.807.085) & Rp. (1.660.407.758) \\
bukuan yang dilakukan Penerimaan & Rp. 5.182.115.057 & Rp. 3.709.627.843 \\
kembali telah hapus buku Koreksi & - & - \\
atas rekening administrative & - & - \\
Penyesuaian akibat penerapan PSAK & - & - \\
Saldo akhir tahun & Rp.(13.766.883.068) & Rp.(14.204.503.871) \\
\hline
\end{tabular}

Sumber: Data diolah, 2017

Dari tabel 2 di atas, terlihat bahwa PT. Bank BRI Agroniaga, Tbk pada tahun 2016 membentuk dana CKPN sebesar Rp. 13.766883.068,meningkatnya pembentukan CKPN dari tahun 2015 sebesar Rp. 1.660.407.758 ke tahun 2016 sebesar Rp.11.392.807.085 dikarenakan menurunnya total kredit dan menurunnya jumlah kredit macet posisi hingga akhir tahun 2015 ke akhir tahun 2016, hal ini dikarenakan telah dilakukan penyelesaian kredit dengan cara eksekusi lelang.

Pembentukan dana CKPN untuk bank menurut Pedoman Akuntansi Perbankan Indonesia, evaluasi kredit dikelompokkan dalam dua kelompok, yaitu secara individual dan secara kolektif. Perhitungan pembentukan CKPN berdasarkan aturan perbankan dijelaskan pada tabel 3, 4 dan 5 berikut. 
Tabel 3.

Pembentukan Cadangan Kerugian Penurunan Nilai PT. Bank BRI Agroniaga, Tbk Tahun 2016 Berdasarkan Aturan Perbankan - Individual Impairment

\begin{tabular}{c|l|r}
\hline & \multicolumn{1}{|c}{ Keterangan } & \multicolumn{1}{|c}{ Jumlah } \\
\hline (a) & Saldo Awal Kredit tahun 2016 & Rp.316.896.153.657 \\
(b) & Saldo Akhir Kredit tahun 2016 & Rp.328.790.437.850 \\
(c) & Suku Bunga Efektif & $15.00 \%$ \\
(d) & Nilai Kredit sebelum Terjadi Penurunan & Rp. 4.183 .341 .104 \\
(e) & NPV dari Future Cash Flow & Rp. 4.097.820.888 \\
$($ f = d - e) & Pembentukan Dana CKPN & Rp. 85.520 .216 \\
\hline
\end{tabular}

Sumber: Data diolah, 2017

Tabel 4.

Pembentukan Cadangan Kerugian Penurunan Nilai PT. Bank BRI Agroniaga, Tbk Tahun 2016 Berdasarkan Aturan Perbankan - Collective Impairment

\begin{tabular}{|c|c|c|c|c|c|}
\hline $\begin{array}{c}\text { Kelompok } \\
\text { Kredit }\end{array}$ & Jumlah & $\% \mathrm{PD}$ & $\%$ LGD & $\% \mathrm{CKPN}$ & CKPN \\
\hline & (a) & (b) & (c) & $(\mathrm{d}=\mathrm{b} \times \mathrm{c})$ & $(\mathrm{e}=\mathrm{a} \times \mathrm{d})$ \\
\hline Lancar & Rp 304.984.497.880 & $0,42 \%$ & $89,84 \%$ & $0,38 \%$ & Rp 1.150.791.906 \\
\hline $\mathrm{DPK}$ & Rp $\quad 8.786 .988 .139$ & $0,09 \%$ & $89,84 \%$ & $0,08 \%$ & $\mathrm{Rp} \quad 7.104 .807$ \\
\hline Kurang Lancar & 12.663 .985 & $7,48 \%$ & $89,84 \%$ & $6,72 \%$ & 33.067 .481 \\
\hline Diragukan & 492.073 .261 & $5,09 \%$ & $89,84 \%$ & $4,57 \%$ & 579.106 \\
\hline Macet & $\mathrm{Rp} \quad 14.514 .214 .585$ & $17,11 \%$ & $89,84 \%$ & $15,37 \%$ & Rp 2.231.070.493 \\
\hline Total & Rp 328.790.439.886 & & & & Rp 3.422.613.792 \\
\hline
\end{tabular}

Sumber: Data diolah, 2017

Tabel 5.

Total Pembentukan Cadangan Kerugian Penurunan Nilai PT. Bank BRI Agroniaga, Tbk Tahun 2016 Berdasarkan Aturan Perbankan

\begin{tabular}{l|c|c|c}
\hline $\begin{array}{l}\text { PT. Bank BRI } \\
\text { Agroniaga, Tbk }\end{array}$ & $\begin{array}{c}\text { Secara Individual } \\
\text { (Individual Impairment) } \\
\text { (a) }\end{array}$ & $\begin{array}{c}\text { Secara Kolektif } \\
\text { (Collective Impairment) } \\
\text { (b) }\end{array}$ & $\begin{array}{c}\text { Total } \\
(\mathrm{c}=\mathrm{a}+\mathrm{b})\end{array}$ \\
\hline $\begin{array}{l}\text { CKPN Tahun } \\
2016\end{array}$ & Rp. 85.520.216 & Rp 3.422.613.792 & Rp. 3.508.134.008 \\
\hline
\end{tabular}

Sumber: Data diolah, 2017

Dari tabel 5 di atas, dapat disimpulkan bahwa pembentukan CKPN yang telah diakui PT. Bank BRI Agroniaga, Tbk 2016 telah sesuai berdasarkan aturan perbankan (PAPI, 2008).

Berdasarkan data laporan keuangan PT. Bank BRI Agroniaga, Tbk tahun 2016, membentuk dana CKPN sebesar Rp. 3.508.134.008 dan terjadi koreksi negatif terhadap pembentukan CKPN PT. Bank
BRI Agroniaga, Tbk tahun 2016 sebesar Rp. 13.893.725.347.

Pembentukan dana cadangan yang boleh dibebankan sebagai biaya menurut pajak didasarkan pada Peraturan Menteri Keuangan No. 81/PMK.03/2009. Perhitungan dana cadangan yang boleh dibebankan sebagai biaya menurut Peraturan Menteri Keuangan No. 81/PMK.03/2009 dijelaskan pada tabel 6 berikut. 
Berdasarkan tabel 6 di atas, kredit lancar adalah surat utang negara dan kontribusi dana cadangan yang boleh sertifikat Bank Indonesia, dan untuk dibebankan adalah Rp. 17.401.859.355, kelompok kredit dalam perhatian khusus yang mana biaya terbesar adalah dari kelompok kredit lancar. Nilai pengurang yang di maksud pada kolom ke tiga, untuk (DPK), kurang lancar, diragukan dan macet adalah nilai agunan dari masing-masing kelompok kredit.

Tabel 6.

Perhitungan Cadangan Kerugian Penurunan Nilai PT. Bank BRI Agroniaga, Tbk Tahun 2016 Berdasarkan Peraturan Menteri Keuangan No. 81/PMK.03/2009

\begin{tabular}{|c|c|c|c|c|}
\hline $\begin{array}{c}\text { Kelompok } \\
\text { Kredit }\end{array}$ & $\begin{array}{l}\text { Kredit yang diberikan } \\
\text { (a) }\end{array}$ & $\begin{array}{l}\text { Nilai Pengurang } \\
\text { (b) }\end{array}$ & $\begin{array}{l}\% \\
\text { Pajak } \\
\text { (c) }\end{array}$ & $\begin{array}{c}\text { Cadangan yang } \\
\text { boleh dibebankan } \\
\text { sebagai biaya } \\
(\mathrm{d}=(\mathrm{a}-\mathrm{b}) \mathrm{x} \text { c })\end{array}$ \\
\hline Lancar & Rp. 304.984.497.880 & Rp. 50.871.414.246 & $1 \%$ & Rp. 2.541 .130 .836 \\
\hline DPK & Rp. $\quad 8.786 .988 .139$ & Rp. $\quad 100.171 .665$ & $5 \%$ & Rp. $\quad 434.340 .824$ \\
\hline Kurang Lancar & 12.663 .985 & 6.544 .574 & $15 \%$ & Rp. $\quad 72.829 .303$ \\
\hline Diragukan & Rp. $\quad 492.073 .261$ & 149.435 & $50 \%$ & Rp. $\quad 6.257 .275$ \\
\hline $\begin{array}{l}\text { Macet } \\
\text { Total }\end{array}$ & Rp. $\quad 14.514 .214 .585$ & 166.913 .468 & $100 \%$ & Rp 14.347.301.117 \\
\hline & Rp. 328.790 .439 .886 & & & Rp. 17.401.859.355 \\
\hline
\end{tabular}

Sumber: Data diolah, 2017

Koreksi fiskal terhadap pem- Tbk yang seharusnya dijelaskan pada tabel 7 bentukan CKPN PT. Bank BRI Agroniaga, berikut.

Tabel 7.

Koreksi Fiskal terhadap Cadangan Kerugian Penurunan Nilai PT. Bank BRI Agroniaga, Tbk tahun 2016 Menurut Aturan Pajak

\begin{tabular}{c|c|c|c}
\hline $\begin{array}{c}\text { Tahun } \\
2016\end{array}$ & $\begin{array}{c}\text { PT. Bank BRI } \\
\text { Agroniaga, Tbk } \\
\text { (a) }\end{array}$ & $\begin{array}{c}\text { Menurut } \\
\text { Pajak/Fiskal } \\
\text { (b) }\end{array}$ & $\begin{array}{c}\text { Koreksi Beda } \\
\text { Temporer } \\
(\mathrm{c}=\mathrm{a}-\mathrm{b})\end{array}$ \\
\hline CKPN & Rp. 3.508 .134 .008 & Rp. 17.401.859.355 & Rp. (13.893.725.347) \\
\hline
\end{tabular}

Sumber: Data diolah, 2017

Berdasarkan tabel 7, diketahui bahwa terdapat perbedaan jumlah koreksi fiskal yang diakui oleh PT. Bank BRI Agroniaga, Tbk tahun 2016 dengan koreksi fiskal menurut aturan pajak.

\section{PENUTUP}

\section{Simpulan}

Berdasarkan hasil analisis dan uraian di atas, maka dapat diperoleh simpulan pembentukan dana CKPN yang diakui oleh PT. Bank BRI Agroniaga, Tbk tahun 2016 telah sesuai dengan aturan perbankan (PAPI, 2008) dan pembentukan dana CKPN PT. Bank BRI Agroniaga, Tbk tahun 2016 yang 
boleh dibebankan sebagai biaya menurut pajak telah sesuai dengan aturan perpajakan (Peraturan Menteri Keuangan No.81/PMK.03/2009) serta, koreksi fiskal pembentukan dana CKPN yang telah dibentuk PT. BANK BRI AGRONIAGA, TBK telah sesuai dengan aturan perpajakan.

\section{Saran}

Peneliti menyarankan baik untuk pihak perbankan maupun pihak perpajakan, diharapkan kedepannya menemukan solusi untuk menciptakan sebuah pedoman baru dalam perhitungan pembentukan cadangan kerugian penurunan nilai untuk menghindari terjadinya perbedaan jumlah cadangan kerugian penurunan nilai yang diakui oleh kedua belah pihak. Untuk penelitian selanjutnya diharapkan untuk lebih update dengan adanya peraturan terbaru yang mengatur tentang pembentukan dana cadangan untuk perbankan ataupun perpajakan, salah satu contohnya adalah revisi terbaru PSAK 50 dan 55 tahun 2016 yang berlaku mulai tanggal 1 Januari 2012.

\section{DAFTAR PUSTAKA}

Alley, Clinton dan James, Simon. 2005. The Interface Between Financial Accounting and Tax Accounting: A Summary of Current Research. Department of Accounting Working Paper Series 84.The University of Waikato.

Amelia, Shelvy., Syafitri Lily dan Wenny, Cherrya Dhia. 2017. Analisis Koreksi Fiskal Terhadap Perhitungan Penyusutan Aset Tetap Pada CV. Mitra Agro Permai. Jurusan Akuntansi Sekolah Tinggi Ilmu Ekonomi Multi Data Palembang. http://eprints.mdp.ac.id/id/eprint/707. Diakses tanggal 23/06/2017.
Cormier, D. and Gordon, I. 2001.An Examination of Social and Environmental Reporting Strategies. Accounting, Auditing \& Accountability Journal, 14(5), pp: 587-616.

Damayanti, Theresia Woro. 2004. Pelaksanaan Self Assesment System Menurut Wajib Pajak (Studi Kasus pada Wajib Pajak Badan Salatiga). Jurnal Ekonomi dan Bisnis, 10(1): h:109-128.

Deegan, C. 2002. The Legitimizing Effect of Social and Environmental Disclosures - A Theoretical Foundation. Accounting, Auditing and Accountability Journal, 15(3), pp. 282-311.

Dita, Irene Maria dan Khairani, Siti.2017. Analisis Penerapan Laporan Rekonsiliasi Fiskal Terhadap Laporan Keuangan Komersial Pada PT. Citra Karya Sejati Palembang.Jurusan Akuntansi S1 Sekolah Tinggi Ilmu Ekonomi Multi Data Palembang.http://eprints.mdp.ac.id/id/ eprint/722. Diakses tanggal 24/06/2017.

Dowling, J. B., \& Pfeffer, J. 1975. Organizational legitimacy: Social values and organizational behavior. Pacific Sociological Review, 18(1), pp: 122-136.

Duhanxhiu, Ilda dan Kapllani, Valbona. 2012. The Relationship Between Financial and Tax Accounting in Albania. The Romanian Economic Journal, 15(43).

Febriati, Ekaputri Ciptani. 2017. Analisis Penerapan PSAK 55 atas Cadangan Kerugian Penurunan Nilai. Jurnal EMBA, 1(3), h: 207-217. 
Feldman, R. 1997. Banks and a big change in technology called credit scoring Federal Reserve Bank of Minneapolis The Region, pp: 19-25.

Green, S. 1995. Accounting Standards and Tax law: Complexity, Dynamism and Divergence. British Tax Review, pp: 445-451.

James, Simon. 2002. The Relationship Between Accounting and Taxation. University of Exeter. https://eric.exeter.ac.uk/repository/bit stream/handle/10036/47557/0209.pdf ? sequence $=1$. Diakses tanggal 30/06/2017.

Lauwrensius, Gracia Stephani., Khairani, Siti dan Ridhwan, M. 2017. Rekonsiliasi Fiskal atas Laporan Keuangan Fiskal untuk Menghitung PPh Badan Terhutang pada PT. Fajar Selatan Palembang.Jurusan Akuntansi Sekolah Tinggi Ilmu Ekonomi Multi Data Palembang. http://eprints.mdp.ac.id/id/eprint/683. Diakses tanggal 22/06/2017.

Lumbantoruan, Amber. 2002. Analisis Perbedaan Perhitungan Laba Kena Pajak Menurut Laporan Keuangan Komersial dan Laporan Keuangan Fiskal.Jurnal Ilmiah Akuntansi, 1(2). Fakultas Ekonomi Jurusan Akuntansi Universitas Jendral Soedirman.

Menteri Keuangan Republik Indonesia.2009. Peraturan Menteri Keuangan Nomor 81/PMK.03/2009 tentang Pembentukan atau Pemupukan Dana Cadangan yang Boleh\Dikurangkan sebagai Biaya . http://www.ortax.org/ortax/? $\bmod =a t u$ ran\&id_topik $=\& i d \_j e n i s=\& p \_t g l=t a h$ un\&tahun $=\&$ nomor $=\& q=D A N A \% 20$
CADANGAN\%2OYANG\%20BOLEH\% 20DIKURANGKAN\%20SEBAGAI\%2 OBIAYA\&q_do=macth $\&$ cols $=i$ si $\& x=6$ $9 \& y=7 \&$ hlm $=1 \&$ page $=$ show $\& i d=137$ 76. Diakses tanggal 20/11/2017.

Mills, Lillian., Newberry, Kaye dan Trautman, William B. 2002. Trends in Book-Tax Income and Balance Sheet Differences.Digital Collections of Australian National University Research.

Natalia, Justin dan Syafitri, Lili. 2017. Rekonsiliasi Fiskal Atas Laporan Keuangan Komersial Untuk Menghitung PPh Badan Pada Perusahaan CV Tamba Palembang. Jurusan Akuntansi Sekolah Tinggi Ilmu Ekonomi Multi Data Palembang.http://eprints.mdp.ac.id/id/ eprint/723. Diakses tanggal 24/06/2017.

Pahala, Indra., Jaya, Tresno Eka dan Meilisa, Grace Ombun. 2012. Pengaruh Perbedaan Laba Akuntansi dan Laba Fiskal serta ROA Terhadap Cumulative Abnormal Return pada Perusahaan Manufaktur yang Terdaftar di Bursa Efek Indonesia pada Tahun 2009.Econo Sains, 10(2).

Patten, D.M. 1991. Exposure, legitimacy, and social disclosure, Journal of Accounting and Public Policy, 10, pp. 297-308.

Phillips, John., Pincus, Morton dan Rego, Sonja Olhoft. 2003. Earnings Management: New Evidence Based on Deferred Tax Expense. The Accounting Review. 78, pp: 491-521.

Purwanti, Nika Sheila., Hardi dan Hasan, Mudrika Alamsyah. 2017. Pengaruh Perbedaan antara Laba Akuntansi dan Laba Fiskal terhadap Persistensi 
Laba pada Perusahaan yang Listing di Bursa Efek Indonesia. http://repository.unri.ac.id:80/handle/ 123456789/1710. Jurusan Akuntansi Fakultas Ekonomi Universitas Riau.

Sari, Elisa Delima dan Lidyah, Rika. 2017. Analisis Koreksi Fiskal dalam Rangka Perhitungan PPh Badan pada PT. Asuransi Bumiputera Cabang Sekip Palembang. Jurusan Akuntansi SI Sekolah Tinggi Ilmu Ekonomi Multi Data Palembang. http://eprints.mdp.ac.id/id/eprint/727. Diakses tanggal 22/06/2017.

Shaviro, Daniel. 2008. Optimal Relationship between Taxable Income and Financial Accounting Income: Analysis and a Proposal, The. Geo. LJ 97 pp: 423-484.
Suchman, M. C. 1995. Managing Legitimacy: Strategic and Institutional Approaches.Academy of Management Journal, 20(3), pp. 571610.

Wijayanti, Handayani Tri. 2006. Analisis Pengaruh Perbedaan antara laba akuntansi dan Laba Fiskal terhadap Persistensi laba, Akrual dan Arus Kas.Simposium Nasional Akuntansi 9 Padang, Agustus 2006.Sekolah Tinggi Ilmu Ekonomi Atma Bakti Surakarta.

Zaenuddin, Achmad. 2007. Faktor-Faktor yang Berpengaruh terhadp Praktek Pengungkapan Sosial dan Lingkungan Pada Perusahaan Manufaktur Go Publik. Tesis.Program Magister Sains Akuntansi Program Pascasarjana Universitas Diponegoro Semarang. 